\title{
Tarih Öğretmen Adaylarının Programdaki Değerlere İlişkin Değer Hiyerarşileri, Gerekçeleri ve Önerileri
}

DOI: $10.26466 /$ opus.404219

\section{Tercan Yildırım*}

\author{
*Dr. Öğr. Üyesi Ahi Evran Üniversitesi, Eğitim Fakültesi, Kırşehir / Türkiye \\ E-Posta: tercan_y@hotmail.com \\ ORCID: 0000-0002-9895-7307
}

\section{Öz}

Bireylerin tüm özel ve toplumsal davranış tercihlerinin stralandığı bir değerler tipolojisi olduğu yaygın kabul görmektedir. Zamanla düşünce yerini, her insanın var olan değerlerden kendine has, kişisel ve esnek hiyerarşiler oluşturduğuna bırakmıştır. Bir kimsenin değerler stralamasının birinci veya en üst sırasında bulunan değeri, onun temel değeri sayılabilir. Değerler bir kişiye verilip onların bir stralaması yaptırıldığında, kişinin en yukarıya koyduğ $u$ değer onun en önemsediği değer olmaktadır. Birey bu tercihini yaparken içinde yaşadı̆̆ değer dünyasina göre bir siralama yapmaktadır. Bu bağlamda araştırmada tarih öğretmen adaylarının programdaki değerlere ilişkin değer hiyerarşilerini nedenleri ile ortaya çıkarmak amaçlanmıştır. Araştırmada nitel araştırma yöntemlerinden durum çalışması kullanılmıştır. Çalışma grubunu, 2017-2018 eğitim-öğretim yılında bir devlet üniversitesinde pedagojik formasyon eğitimi alan tarih öğretmen adaylar oluşturmaktadır. Araştırmada kullanılan yapılandırılmış görüşme formu açık uçlu 4 sorudan oluşmaktadır. Tarih Dersi Öğretim Programı'nda yer alan değerleri kendilerince önem derecesine göre (ilk 3 değer) stralamaları ve gerekçelerini ifade etmeleri istenmiştir. Araştırma kapsamında elde edilen verilerin çözümlenmesinde içerik analizi türlerinden tümevarımcı analiz kullanılmıştır. Vatanseverlik, adalet ve dürüstlük değerleri öğretmen adayları tarafından ilk üç değer arasında sırlanmıştır. Öğretmen adayları ilk üç değerin çoğunlukla öğretmenden kazanılması gerektiğini ifade etmişlerdir. Bunların yanı sıra tarihi/dini karakterlerden ve edebi eserlerden de kazanılabileceği ifade edilmiştir. Bu değerlerin kazandırlmasında izlenecek yöntemler konusunda ise model olunması, örnekler verilmesi, uygulama yaptırılması, çeşitli tarihsel geziler yapılması, tarihsel film-belgesel izletilmesi ve öğretmen tarafından kavramsal olarak açıklama yapılması gibi öneriler getirilmiştir.

Anahtar Kelimeler:Tarih öğretimi, öğretmen adayı, değer eğitimi, değer hiyerarşisi 


\title{
Value Hierarchies, Reasons and Recommendations of Pre-Service History Teachers Regarding Value in the History Curriculum
}

\begin{abstract}
It is widely accepted that individuals are a typology of values that rank all their preferences for private and social behavior. Over time, he left the place of thought as a way of creating individual, flexible hierarchies of each person's unique values. The value of a person's first or top rank of values can be counted as his or her basic value. When the values are given to one person and they are ordered, the value that the person places at the top is the value that he cares the most. The individual makes an order according to the value world they live in when making this choice. In this context, it was aimed to reveal the value hierarchies of the history teacher candidates about the values in the program. The case study was used in the research qualitative research methods. The working group constitutes history teacher candidates trained in pedagogical formation at a state university during the 2017-2018 academic year. The structured interview form used in the research consists of 4 open-ended questions. It is requested that the values in the History Course Curriculum be sorted according to their importance (the first 3 values) and to express their justifications. In the analysis of the data obtained from the research, the sample analysis was used from the content analysis types. The values of patriotism, justice and honesty are ranked among the first three values by prospective teachers. Teacher candidates stated that the first three values should be earned mostly from the teacher. In addition to these, it is stated that they can be won from historical I religious characters and literary works. On these methods, some suggestions such as modeling, giving examples, making applications, making various historical trips, watching historical films and documentaries and making conceptual explanations by the teachers have been introduced.
\end{abstract}

Keywords: History teaching, pre-service teacher, value education, value hierarchies 
Tarih Öğretmen Adaylarının Programdaki Değerlere İlişkin Değer Hiyerarşileri, Gerekçeleri ve Önerileri

\section{Giriş}

Toplumsal düzeni sağlama ihtiyacı bireylerin düşünce, davranış ve tutumlarının değerler eliyle belli bir standarta bağlanması ile sonuçlanmıştır. Bireylerin etik ya da uygun davranışlar hakkında doğru/yanlış ya da istenilir/istenmez olduğuna dair karar alma süreçlerinde değerler bir tür araç niteliği taşırlar (Marshall, 2009; Yazıc1, 2006). Değerler, toplumsal düzen için gerekli olan istendik davranış kalıplarının belirlenmesinde genel ilkeler ve temel inançla olarak tanımlanmaktadır (Halstead ve Taylor, 2000). Benzer şekilde değerlerin, toplumsal hayat içinde bireye ya da gruplara yol gösterici ilkeleri ve arzu edilen amaçları belirlemesine dikkat çekmektedir (Schwartz, 1992; Çelikkaya ve Kürümlüoğlu, 2017).

Toplumsal hayatın düzenli ve sorunsuz bir şekilde devam edebilmesi için öncelikli olarak bu hayata nizam veren değerlerin tüm bireyler tarafından benimsenmesi ve içselleştirilmesi gerekmektedir. Bu gereklilik ise eğitime önemli görevler yüklemektedir (Tezcan, 1999). Değerler eğitimine olan söz konusu ihtiyacı Çelikkaya (2016), "toplumları olumsuz yönde etkileyen durumları önlemenin en etkili yolu, toplumun devamlılığını ve ayakta kalmasını sağlayan unsurların başında gelen değerleri kazandırmak" olarak belirtmektedir. Toplumsal beklentilerin bireylere aktarılması, benimsetilmesi ve tanitılması ihtiyacı değerler eğitimi sürecine önemli görevler yüklemektedir (Veugelers ve Vedder, 2003; akt. Yıld1rim, 2017).

Bilindiği gibi değerler eğitimi ilk olarak ailede başlamaktadır. Planlı ve programlı bir eğitim değerler eğitim süreci ise ancak okullarda mümkün olabilmektedir. Bu niteliğinden dolayı okul, bireylere değerlerin öğretilmesinde en önemli kurum olarak karşımıza çıkar. Temel amacı vatandaş yetiştirmek olan okullarda değerler eğitimi süreci aslında vatandaşın nasıl olması gerektiği sorusuna verilen yanıt niteliğindedir. Öyle ki okulların, öğrencileri hayata hazırlamak, ait olduğu toplumun tüm değerlerini benimsetmek ve bu değerlere göre davranış oluşturmalarını sağlamak gibi amaçlar özünde vatandaşı tanımlamaya dönüktü (Çelikkaya ve Yakar, 2015; Mutluer, 2015; Yeşil ve Aydın, 2007; Yıldırım, 2017). Okullar var olan toplumsal kültür ve değerlerin korunması ve sürdürülmesinin yanında yeni değerlerin oluşturulmasında da merkezi 
bir rol üstlenmektedir (Doğan, 2011; Karatekin, Gençtürk ve Kılıçoğlu, 2013).

Ülkemizde değerler eğitimi süreci genel olarak Sosyal Bilimler disiplinleri üzerinden yürütülmekte ve bu süreçte tarih eğitimine önemli görevler düşmektedir. Tarih derslerinin sadece geçmişim bilgisi veya belli becerileri kazandırmak üzerine kurgulanmadığı, aynı zamanda tarih öğrencilerinin duyuşşal alanine hitap ettiği bilinmektedir. Zira amaçları bağlamında tarih eğitimine bakıldığında geleneksel olarak vatandaşlık eğitimi ve kimlik aktarımını temel alındığı görülür (Dilek, 2007; Demircioğlu, 2010). Zira milli eğitim politikalarının temel hedefi olan bilinçli, kültürlü, değerlerine sahip yurttaş yetiştirmede tarih eğitiminin önemli bir yeri vardır (Safran, 1993; Ulusoy, 2010). Özellikle kültürel değerlerin aktarılmasında önemli bir rol oynamaktadır (Nichol, 1996; Dewey, 2000). $\mathrm{Bu}$ derslerde genel olarak geçmişin bilgisi üzerinden öğrencilere kendi tarihini, toplumunu ve kültürünü tanıtmak ve böylece sosyalleşmesini sağlamak amaçlanmaktadır (Paykoç, 1991). Böylece tarih ile sosyal bilgiler dersleri bir nevi eşitlenmiş olur (Yazıcı, 2011; Yıldırım, 2016). Ulusoy'a (2005) göre tarih geçmişten derslerçıkarmamızı sağlayarak tarihsel ve kültürel değerleri öğrencilere aktarmada oldukça önemli bir araçtır. Özellikle tarih derslerinde var olan geçmişe dair örnek olaylar hem yeni değerler kazandırılmasında hem de mevcut değerlerini sorgulanmasında diğer sosyal bilim disiplinleri ile karşılaştırıldığında daha avantajlı bir durumdadır (Tokdemir ve Demircioğlu, 2008).

Günümüzde Türkiye'de her ne kadar yapılandırmacı tarih öğretimi dair programlar ve ders kitapları kullanılsa da geleneksel yaklaşımın daha etkin olduğu ve öğretmenlerin merkezi konumunu sürdürdüğü görülür. Bu durum değerler eğitiminde en önemli sorumluluğu öğretmenlere yüklemektedir (Ergün, 1994). Özellikle öğrencilerin sosyalleşmesi açısından değerlendirildiğinde öğretmenlerin rol model olma potansiyeli karşımıza çıkar (Tezcan, 1999). Programlar vasıtasıyla öğrencilere kazandırılması istenen değerlerin öğretmenleri tarafından nasıl alg1landıkları, bu değerlerin hangilerini daha önemli gördükleri eğitim sürecini doğrudan etkilemektedir. Zira insanlar, değer sistemlerini oluşturan bir değerler hiyerarşisine sahiptirler (Aydın, 2005). Bir kişiden, var olan değerleri sıralaması istendiğinde kişinin ilk sıraya koyduğu değerin onun için en önemlisi olduğu yaygın kabul görmektedir. Birey bu sıra- 
lamayı yaparken kendi değer dünyasının etkisinde kalmaktadır (Aydın, 2005; Çelikkaya ve Kürümlüoğlu, 2017; Debats ve Bartelds, 1996; Güngör, 2000). Öğretmenlerin değer eğitiminde birincil konumundan hareketle değer hiyerarşilerini bilmek programların uygulma aşaması için oldukça önemlidir.

$\mathrm{Bu}$ açıdan bakıldığında öğretmenler değerler eğitimi sürecinde tarafsız olduklarını söylemek güçtür (Karatekin, Gençtürk ve Kılıçoğlu, 2013). Öyle ki öğretmenler ders anlatırken kendi değer yargılarını daha öne çıkartmaktadırlar (Doğan, 2011).

Bu bağlamda 2018 Tarih Dersi Öğretim Programı incelendiğinde öğrencilere "adalet, dostluk, dürüstlük, öz denetim, sabır, sayg1, sevgi, sorumluluk, vatanseverlik, yardımseverlik" olarak toplam 10 kök değerin ve bu değerlere ilişkin tutum ve davranışların kazandırılmasının hedeflenmektedir. Programda değerler eğitimini bütüncül olarak tüm programı kapsadığı ve merkezi bir konumda olduğu sıklıkla belirtilmektedir (MEB, 2018).

Türkiye'de tarih öğretiminde değerler eğitimi ile ilgili yayımlanan çalışmalara bakıldığında değer ve değerler eğitimine ilişkin öğrenci ve öğretmen görüşleri (Tokdemir, 2007; Ulusoy, 2007a, 2007b; Yiğittir ve Öcal, 2011), tarih öğretiminin amaçları bağlamında değer-beceri ilişkisi (Tokdemir, 2016), tarih öğretim programında ve ders kitaplarında değerler eğitimi (Ulusoy, 2010; Keskin, 2015), genel olarak tarih dersleri değer aktarımı ilişkisi (Ulusoy, 2005; Demircioğlu ve Tokdemir, 2008; Gültekin, 2011; Gülmüş, 2015), bazı değer ifadeleri üzerine üzerine yapılan (Mutluer, 2015) çalışmalar mevcut olmasına rağmen 2018 tarih dersi öğretim programında yer alan değerlerin hiyerarşisine dönük herhangi bir çalışmaya rastlanmamıştır.

$\mathrm{Bu}$ bağlamda araştırmada pedagojik formansyon eğitimine kapsamında tarih öğretmen adaylarının 2018 Tarih Programı'nda var olan 10 kök değer içinden ilk 3 değer tercihini sıralamaları, bu değerleri niçin seçtikleri istenmiş olup bu değerlerin öğretim yöntemine ilişkin önerilerin neler olabileceğini belirlemek amaçlanmıştır. Böylece tarih öğretmen adaylarının Tarih Dersi Öğretim Programı'nda yer alan değerler içinde en fazla önem verdikleri değerler ile en az önem verdikleri değerlerin neler olduğu da tespit edilecektir. Aynı zamanda ileride değer aktarımı yapma potansiyeli olan öğretmen adaylarının sahip oldukları değerlerin 
profilini çıkarabilmek için onların değer hiyerarşileri ortaya konacaktır. Bu noktada tarih öğretmen adaylarının sahip oldukları değer hiyerarşisin bilmek programda belirtilen değerleri kazandırmak için oldukça önemli olduğu söylenebilir.

\section{Yöntem}

$\mathrm{Bu}$ araştırmada öğretmen adaylarının sahip oldukları değer hiyerarşilerini nedenleri ile ortaya koyabilmek adına nitel araştırma yöntemlerinden durum çalışması kullanılmıştır. Durum çalışmaları, nitel araştırmada çok yaygın olarak kullanılan bir yaklaşımdır ve genel olarak 'nasıl' ve 'niçin' sorularını temel alır. Burada bir ya da birkaç durumun derinliğine araştırılması ön plana çıkar (Yıldırım ve Şimşek, 2008). Bu tür çalışmalarda durumu, öğretmen, öğrenci ya da program oluşturabilmekte ve araştırmacılara zengin veriler sunabilmektedirr. Aynı zamanda elde edilen veri seti bütüncül bir yaklaşımla yorumlanabilmektedir (Yin, 2003; Yaşar ve Çengelci, 2012).

\section{Çalışma Grubu}

Çalışma grubu, 2017-2018 eğitim-öğretim yılında bir devlet üniversitesinde pedagojik formasyon eğitimine devam eden 61 tarih öğretmen adayından oluşmaktadır.

\section{Veri Toplama Aracı ve Analizi}

Veri toplama aracı olarak açık uçlu 4 sorudan oluşan yapılandırılmış görüşme formu kullanılmıştır. Araştırma kapsamında elde edilen verilerin çözümlenmesinde içerik analizi türlerinden tümevarımcı analiz kullanılmıştır. Tümevarımcı analiz kodlama yoluyla verilerin altında yatan kavramları ve bu kavramlar arasındaki ilişkileri ortaya çıkarmak amacıyla yapılmaktadır (Yıldırım ve Şimşek, 2008). 
Tarih Öğretmen Adaylarının Programdaki Değerlere İlişkin Değer Hiyerarşileri, Gerekçeleri ve Önerileri

\section{Bulgular ve Yorumlar}

Tablo 1: Öğretmen Adaylarının Öğrencide Bulunmasını İstediği İlk 3 Değer Hiyerarşisi

\begin{tabular}{llcc}
\hline Değerler & Değer Siralamasi & $\%$ & $\mathbf{f}$ \\
\hline Vatanseverlik & 1. Değer & 41 & 25 \\
\hline Adalet & 2. Değer & 26 & 16 \\
\hline Dürüstlük & 3. Değer & 15 & 9 \\
\hline
\end{tabular}

Tarih öğretmen adaylarının “Tarih Dersi Öğretim Programı'nda kazandırılması gereken 10 değerden ilk üç değeri seçip 1 ile 3 arasında sıralayını" sorusuna verdiği cevaplar Tablo 1. de verilmiştir. Tabloya göre öğretmen adaylarının ilk üç değere ilişkin yaptığı sıralamada vatanseverlik, adalet ve dürüstlük ön plana çıkmıştır. Bu sıralama incelendiğinde ilk sıradaki vatanseverlik değerinin \% 41; ikinci sıradaki adalet değerini \% 26 ve üçüncü sıradadaki dürüstlük değerini \% 15 gibi bir oranla ifade ettikleri görülmüştür.

Tablo 2: Değerlerin Öğretmen Adaylarının Tercihlerine Göre İlk Üçe Girme Durumuna İlişkin Bulgular

\begin{tabular}{|c|c|c|c|c|}
\hline Değerler & 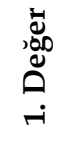 & 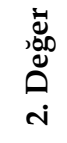 & 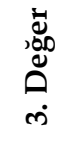 & $\begin{array}{l}\text { Toplam } \\
\text { (f) }\end{array}$ \\
\hline Adalet & 16 & 20 & 10 & 46 \\
\hline Dostluk & 1 & - & 4 & 5 \\
\hline Dürüstlük & 9 & 12 & 10 & 31 \\
\hline Öz denetim & 2 & - & 2 & 4 \\
\hline Sabir & 2 & 3 & 5 & 10 \\
\hline Sayg1 & 3 & 5 & 12 & 20 \\
\hline Sevgi & 1 & 2 & 2 & 5 \\
\hline Sorumluluk & 2 & 7 & 10 & 19 \\
\hline Vatanseverlik & 25 & 12 & 5 & 42 \\
\hline Yardımseverlik & - & - & 1 & 1 \\
\hline
\end{tabular}

Araştırmaya katılana öğretmen adaylarının programda yer verilen değerleri sıralamaya koyduklarında ilk üçe giren değerlerin frekansları 
Tablo 2. de verilmiştir. Tablo incelendiğinde öğretmen adaylarının ilk sırada 9 değere yer verdiği görülmektedir. Buna göre öğretmen adaylarının birinci sırada gelen değerlerinin başında vatanseverlik (25) olduğu belirlenmiştir. Bu değerin ardından sırasıyla adalet (16) ve dürüstlük (9) değeri öne çıkmaktadır. İkinci sırada toplamda 7 değere yer verilmiş olup ilk sırada adalet (20) değeri, ardından ise vatanseverlik (12) ve dürüstlük (12) gelmektedir. Üçüncü sırada ise ilk olarak sayg1 (12), ardından dürüstlük (10), sorumluluk (10) ve adalet (10) değerleri gelmektedir.

Tablo 3. Değerlerin Niçin Kazandırılması Gerektiğine İlişkin Öğretmen Adaylarının Görü̈sleri

\begin{tabular}{llc}
\hline \multicolumn{1}{c}{ SıraNo/Değer } & \multicolumn{1}{c}{ Gerekçe } & $f$ \\
\hline \multirow{4}{*}{ 1. Vatanseverlik } & Vatanına sahip çıkmak için & 9 \\
& Vatanını sevmeyene güvenilemeyeceği için & 7 \\
& Ülkeye faydalı olmak için & 6 \\
& Kendini, ailesini, tarihini sevmesi için & 4 \\
& Birlik-beraberlik içinde yaşamak için & 1 \\
\hline \multirow{5}{*}{ 2. Adalet } & Hak- hukuk çerçevesinde hareket etmek için & 10 \\
& Hayatın her alanında lazım olduğu için & 3 \\
& Birlik-beraberlik içinde yaşamak için & 2 \\
& Sorunsuz insani ilişkiler kurmak için & 2 \\
& Örnek vatandaş olmak için & 1 \\
\hline 3. Dürüstlük & Her koşulda doğruyu söylemek için & 6 \\
& Kişilik için öncelikli olduğu için & 4 \\
& Saygi ve sevginin kaynağı olduğu için & 2 \\
& Yanlış yolda gitmemek için & 2 \\
& Türk olduğumuz için & 1 \\
& Çıkarsız bir dostluk kurmak için & 1 \\
\hline
\end{tabular}

Öğretmen adaylarının “ỉlk üç ile numaralandırdığınız değerlerin kazandırılması sizce niçin önemlidir? Buna ilişkin gerekçelerinizi her bir değer için örnek vererek açıklayınız" sorusuna verdikleri cevaplar Tablo 3 . de verilmiştir. Tablo 3 . incelendiğinde öğretmen adaylarının vatanseverlik değerini vatanına sahip çıkmak (9), vatanını sevmeyene güvenilemeyeceği (7), ülkeye faydalı olmak (6), kendini, ailesini, tarihini 
Tarih Öğretmen Adaylarının Programdaki Değerlere İlişkin Değer Hiyerarşileri, Gerekçeleri ve Önerileri

sevmesi (4) ve birlik-beraberlik içinde yaşamak(1) için; adalet değerinihak- hukuk çerçevesinde hareket etmek (10), hayatın her alanında lazım olduğu (3), birlik-beraberlik içinde yaşamak (2), sorunsuz insani ilişkiler kurmak (2), örnek vatandaş olmak (1) için; dürüstlük değerini iseher koşulda doğruyu söylemek (4), kişilik için öncelikli olduğu (4), saygı ve sevginin kaynağı olduğu (2), yanlış yolda gitmemek (1), Türk olduğumuz (1), çıkarsız bir dostluk (1) ve tarihi çarpitmamak için önceliklekazandırılması gerektiğini olduklarını ifade etmişlerdir.

\section{Vatanseverlik değerinin;}

Vatanına sahip çıkmak için kazandırılması gerektiğini savunan ÖA28 bu durumu "Vatanına bağlı ve onu koruyan insan herkesi korur ve kollar"; ÖA56 ise "Vatanına sahip çıkan insanda sevgi ve saygı değeri zaten oluşmuştur. Bu yüzden vatanseverlik değeri öncelikli olarak kazandırılmalıdır" şeklinde ifade etmektedirler.

Vatanını sevmeyene güvenilemeyeceği için kazandırılması gerektiğini savunan ÖA62 bu durumu "Vatanını sevmeyen bir bireye hayatın hiç bir alanında güvenilemeyeceğini" belirtmektedir. ÖA47 ise "Vatanını sevmeyen birey hiç bir şeyi sevmeyeceği ve saygı duymayacă̆ı için güven vermez" demektedir.

Ülkeye faydalı olmak için kazandırılması gerektiğini savunan ÖA58 bu durumu "Bir kimse herşeyden önce ülkesine fayda sağlamak için yaşamalıdır. Bir insane ancak vatanım severse iyi işler yapar" olarak ifade etmektedir. ÖA23 ise "Vatanını seven bir bireyin faydalı olabilmek için kendini daha çok geliştirip donanıml hale gelmesi gerekir" şeklinde gerekçelendirmektedir.

Kendini, ailesini, tarihini sevmesi için kazandırılması gerektiğini savunan ÖA19 "Yetiştirilecek öğrenciler için birinci öncelik benim için vatanseverliktir. Çünkü bir milletin kendini ve nereden geldiğini bilmesi çok önemlidir. Vatanım, milletini, toprağını, geçmişini, tarihini seven bireyler yetiştirmek asıl vatanseverliktir" ifadeleriyle açiklamaktadır.

Birlik-beraberlik içinde yaşamak için kazandırılması gerektiğini savunan ÖA44 bu durumu "Milli birlik ve beraberliğin birinci şartı vatansever bireylerin varlığıdır" şeklinde açılamaktadır. ÖA61 ise "Vatansever bir 
toplum hiç bir zaman bağımsızlğ̆ın kaybetmez. Çünkü bu duygu bir olmanının diri olmanın temel şartıdır" olarak gerekçelendirmektedir.

Adalet değerinin;

Hak- hukuk çerçevesinde hareket etmek için kazandırılması gerektiğini savunan ÖA15 bu durumu "Adalet bilinci olan bir genç hak yemeden sorunlarının üstesinden gelmeye çalışır" olarak; ÖA42 ise "Adalet kavramı çocŭ̆a kazandirlldıktan sonar aile ve arkadaşlarına eşit şekilde davranabilir, iş hayatında adaletli davranabilir. Insanlar arasinda ayrm yapmadan hayatına devam edebilir" şeklinde açılamaktadır.

Hayatın her alanında lazım olduğu için kazandırılması gerektiğini savunan ÖA17 "Adalet herkes için ve hayatın her alanında lazım olduğu için bireylere bu değerin kesinlikle öncelikli olarak aşılanması..." gerektiğini ifade etmektedir.

Birlik-beraberlik içinde yaşamak için kazandırılması gerektiğini savunan ÖA20 gerekçesini "Adalet duygusunun hakim olduğu bir toplumda haksızlıklar ortadan kalkacağı için birlik içinde yaşamak daha kolay olacaktır" gibi ifadelerle sunmaktadır.

Sorunsuz insani ilişkiler kurmak için kazandırılması gerektiğini savunan ÖA23 bu durumu "Adalet duygusu gelişmiş kişilerin bulunduğu ortamlarda dürüstlük, merhamet ve dostluk üzerine ilişikiler kurulabilir ve böylece insanlar arasında iletişim sorunsuz bir şekilde gerçekleşebilir" olarak açıklamaktadır.

Örnek vatandaş olmak için kazandırılması gerektiğini savunan ÖA33 bu durumu "Yetiştireceğimiz öğrenciler geleceğin doktoru, hakimi, öğretmeni, mühendisi olacağından görevleri sırasında adaletli davranmalar diğer vatndaşlara örnek olabilir" gibi ifadelerle belirtmektedir.

\section{Dürüstlük değerinin;}

Her koşulda doğruyu söylemek için kazandırılması gerektiğini savunan ÖA42 bu durumu "Çocuğun yaşamı anlamaya başlamsından itibaren dürüst davranıp, dürüstlüğ̈̈ hayatına yalan sokmadan sürdürmesi için bu değer önemlidir. Her zaman doğruyu söylemek bazen kendisine sıkıntı bile yaratsa sonunda kazanan o olur" şeklinde açıklamaktadır. ÖA 54 de "Bence her öğrenci her koşulda doğruyu söylemelidir" diyerek benzer bir gerekçe sunmaktadır. 
Tarih Öğretmen Adaylarının Programdaki Değerlere İlişkin Değer Hiyerarşileri, Gerekçeleri ve Önerileri

Kişilik için öncelikli olduğu için kazandırılması gerektiğini savunan ÖA26 bu durumu "Dürüstlük bir insanda olması gereken en önemli karakter özelliğidir. Dürüst değilse birisi ne kendine ne çevresine ne de ülkesine faydal olması imkansızdır" olarak açıklamaktadır.

Saygı ve sevginin kaynağı olduğu için kazandırılması gerektiğini savunan ÖA29' a göre "Dürüstlük en büyük erdemdir. Sayılmak ve sevilmek için dürüstlük bir kaynak niteliğindedir". ÖA47 de benzer şekilde "Dürüstlüğ̈̈̈n olmadı̆̆ı yerlerde sevgi ve saygının olmaz" demektedir.

Yanlış yolda gitmemek için kazandırılması gerektiğini savunan ÖA39 "Dürüst insanlar he zaman doğrunun peşinde olduklarında yanlış yola sapmazlar" demektedir.

Türk olduğumuz için kazandırılması gerektiğini savunan ÖA16 "Dürüstlük insanı yücelten özellikler arasında en başta gelir ve bu değerin Türklük ile doğrudan alakası vardır" demektedir.

Çıkarsız bir dostluk için kazandırılması gerektiğini savunan ÖA56 bu durumu "Dürüst bir insane dürüst olduğu sürece arakdaş ilişkilerinde de să̆lam bir ilişki ve çıkarsız bir dostluk kuracaktır" ifadeleriyle gerekçelendirmektedir.

Tablo 4. Çocukların Değerleri Kimden ve Nasıl Kazanması Gerektiğine İlişkin Öğretmen Adaylarının Görüşleri

\begin{tabular}{|c|c|c|c|c|}
\hline Sıra No/Değer & Kimden & $f$ & Yöntem & $f$ \\
\hline \multirow{6}{*}{ 1. Vatanseverlik } & & & Düz anlatım & 14 \\
\hline & Öğretmen & 29 & Örnek olay & 8 \\
\hline & Dini/tarihi Karakterler & 13 & Gösteri & 5 \\
\hline & Edebi eserler & 2 & Tarihsel gezi & 3 \\
\hline & & & Model olma & 3 \\
\hline & & & Uygulama & 1 \\
\hline \multirow{5}{*}{ 2. Adalet } & & & Örnek olay & 13 \\
\hline & Öğretmen & 37 & Düz anlatım & 12 \\
\hline & Dini/tarihi Karakterler & 5 & Model olma & 12 \\
\hline & Edebi eserler & 1 & Uygulama & 2 \\
\hline & & & Gösteri & 1 \\
\hline \multirow{4}{*}{ 3. Dürüstlük } & & & Düz anlatım & 11 \\
\hline & Öğretmen & 25 & Model olma & 10 \\
\hline & Dini/tarihi Karakterler & 5 & Örnek olay & 8 \\
\hline & & & Uygulama & 2 \\
\hline
\end{tabular}


Öğretmen adaylarının “Öğretmen olduğunuzda çocuklara ilk üç ile numaralandırdığınız değerleri nasıl kazandırmaya çalışırsınız? Buna ilişkin önerilerinizi her bir değer için örnek vererek açıklayınız" sorusuna verdikleri cevaplar Tablo 4 . de verilmiştir. Tablo 4 . incelendiğinde vatanseverlik değerinin en çok öğretmenden (29) sonrasında ise dini/tarihi karakterlerden (13) ve edebi eserlerden (2) kazandırılması gerektiği ifade edilmiştir. Bu değerin kazandırılmasında izlenecek yöntemler ise düz anlatım (14), örnek olay (8), gösteri (5), tarihsel gezi (3), model olma (3) ve uygulama (1) olarak sıralanmıştır. Öğretmen adaylarının değer hiyerarşilerinde ikinci sırada yer alan adalet değerinin de öncelikli olarak öğretmenden (37), dini/tarihi karakterlerden (5) ve edebi eserlerden (1) kazandırılabileceği belirtilmiştir. Adelet değeri için örnek olay (13), düz anlatım (12), model olma (12), uygulama (2) ve gösteri (1) gibi yöntemlerin kullanılması önerilmiştir. Üçüncü sıradaki dürüstlük değerinin ise önceki iki değere benzer şekilde en fazla öğretmenden (25) daha sonar ise dini/tarihi karakterlerden (1) kazandırılabileceği belirtilmiştir. Bu kazanımları sağlamak içinse düz anlatım (11), model olma (10), örnek olay (8), uygulama (1) ve rehberlik (1) gibi yöntemler sıralanmaktadır.

\section{Vatanseverlik değerinin;}

Düz anlatım ile kazandırılması gerektiğini ifade eden ÖA21 bu durumu "Öğrencilerime atalarımızın gösterdiği mücadeleler verdikleri ve vatanımızı nasıl korudukları hakkında konuşma yapardım" diyerek açıklamaktadır.

Örnek olay ile kazandırılması gerektiğini ifade eden ÖA8 bu durumu "Tarihsel şahsiyetler ve olaylar üzerinden çarpıcı örnekler vererek" diye ifade ederken, ÖA55 "Geçmişteki yaşanmış ve günümüzde de etkisi hissedilen olaylardan bahsederek" ÖA56 ise "Vatanı için canın veen şehitleri örnek vererek" şeklinde açılamaktadır.

Gösteri ile kazandırılması gerektiğini ifade eden ÖA13'e göre "Derslerde tarihsel film ve belgesel izletmenin öğrenciler üzerinde daha etkili olacağını" belirtmektedir.

Tarihsel geziile kazandırılması gerektiğini ifade eden ÖA41 bu durumu "Vatansever bir birey olabilmesi için, öncelikle öğrencilerin, Çanakkale 
Tarih Öğretmen Adaylarının Programdaki Değerlere İlişkin Değer Hiyerarşileri, Gerekçeleri ve Önerileri

gibi büyük savaşların kazanıldığı topraklara götürülmesi gerekmektedir" şeklinde açıklamaktadır.

Model olmaile kazandırılması gerektiğini ifade eden ÖA22 bu durumu "Herşeyden önce öğretmen olarak kendi vatanseverliğimi hissettirerek" şeklinde ifade etmektedir.

Uygulama ile kazandırılması gerektiğini ifade eden ÖA23 “Öğrencilerimden terörle mücadele eden askerlerimize mektup, şiir ve resim yazmalarmı isterdim" şeklinde ifade etmektedir.

\section{Adalet değerinin;}

Örnek olay ile kazandırılması gerektiğini ifade eden ÖA38 bu durumu "Adaletli olmayı öğretmen sinıfta yaptığı bir örnek olayla aktarabilir" olarak açıklamaktadır.

Düz anlatımile kazandırılması gerektiğini ifade eden ÖA18 bu duru$\mathrm{mu}$ "Öğrencilerimi adalet kavramını sözel olarak anlatarım" olarak ifade etmektedir.

Model olmaile kazandırılması gerektiğini ifade eden ÖA59 "Öncelikle bir öğretmenin öğrencilerine örnek olması" üzerinde durulmalı derken, ÖA12 ise "Öğretmenin hata yapan bir öğrenciye hatasının boyutuna göre değerlendirip adaletli bir şekilde verdiğ i kararla öğrenci üzerinde etkili olabilir" diye açıklamaktadır.

Uygulamaile kazandırılması gerektiğini ifade eden ÖA15 bu durumu "Öğrencilerime çeşitli proje ve ödevler vererek" şeklinde açıklamaktadır.

Gösteri ile kazandırılması gerektiğini ifade eden ÖA9 bu durumu "Çeşitli filmler izlettirerek" diye belirtmektedir.

Dürüstlük değerinin;

Düz anlatımile kazandırılması gerektiğini ifade eden ÖA27 "Dürüstlüğ̈̈̈̈̆grencilerime kazandırmak için onlara dürüst oldukları zaman bir çok şey kazanacaklarım anlatırım" demektedir.

Model olmaile kazandırılması gerektiğini ifade eden ÖA54 bu durumu "Illk olarak öğrencilerime kendim örnek olurum" şeklinde açıklamaktadır. ÖA42 ise "Öğrencilerime kendim dürüst olurum ki onlardan da aynı davranışı isteyebileyim" demektedir. 
Örnek olay ile kazandırılması gerektiğini ifade eden ÖA11 “Dürüstlük bir bireye verilmesi gereken en büyük etkendir. Bunu da arkadaş ortaminda yapılan bir hatadan ders çıkarmak şeklinde anlatabiliriz" demektedir.

Uygulamaile kazandırılması gerektiğini ifade eden ÖA58 bu durumu "Sınıf içinde etkinlikler yaptırılması" şeklinde açıklamaktadır.

Tablo 5. Değerlerin Hangi Konularla İlişkilendirilebileceğine İlişkin Öğretmen Adaylarının Görüşleri

\begin{tabular}{lll}
\hline Sıra No/Değer & Gerekçe & $f$ \\
\hline & Milli Mücadele ve Kurtuluş Savaşı & 15 \\
& Çanakkale ve I. Dünya Savaşı & 10 \\
& Savaşlar (Genel) & 7 \\
& Mustafa Kemal Atatürk & 6 \\
1. Vatanseverlik & Tarihi Şahsiyetler (Genel) & 3 \\
& Fatih Sultan Mehmet & 1 \\
& İstiklal Marşı & 1 \\
& Şehitler & 1 \\
& Afrin- Zeytin Dalı Operasyonu & 1 \\
\hline & Osmanlı Padişahları & 13 \\
& Hz. Ömer & 6 \\
& Fatih Kanunnamesi ve Osmanlı hoşgörüsü & 4 \\
& Hz. Muhammed & 3 \\
& Türk töresi & 1 \\
& İstiklal mahkemeleri & 1 \\
& Şer'i mahkemeler & 1 \\
& Selçuklu Sultanlar & 1 \\
& Encümeni Daniş & 1 \\
\hline 3. Dürüstlük & Osmanlı Padişahları & 6 \\
& Hz. Muhammed & 5 \\
& Osmanlı esnafları & 1 \\
& Kaybedilen savaşlar & 1 \\
\hline
\end{tabular}

Öğretmen adaylarının “Öğretmen olduğunuzda çocuklara ilk üç ile numaralandırdığınız değerleri hangi konularla ilişkilendirerek kazandırmaya çalışırsınız? Her bir değer için örnek vererek açıklayınız" sorusuna verdikleri cevaplar Tablo 5 . de verilmiştir. Tablo 5. incelendiğinde vatanseverlik değerinin en çok Milli Mücadele ve Kur- 
tuluş Savaşı (15), Çanakkale ve I. Dünya Savaşı (10), Savaşlar (7), Mustafa Kemal Atatürk (6), tarihi şahsiyetler (3), Fatih Sultan Mehmet (1), İstiklal Marşı (1), şehitler (1) ve Afrin-Zeytin Dalı Operasyonu (1) konularıyla ilişki kurarak kazandırmaya çalışacaklarını belirtmişlerdir. Öğretmen adayları adalet değerini ise Osmanlı Padişahları (13), Hz. Ömer (6), Fatih Kanunnamesi ve Osmanlı hoşgörüsü (4), Hz. Muhammed (3), İstiklal mahkemeleri (1), Türk töresi (1), Şer'i mahkemeler (1), Selçuklu Sultanları (1) ve Encümeni Daniş (1) konularıla ilişkilendirebileceklerini belirtmişlerdir. Son olarak ise dürüstlük değerinin Osmanlı Padişahları (6), Hz. Muhammed (5), Osmanlı esnafları (1) ve kaybedilen savaşlar (1) gibi konular üzerinden kazandırılabilceğini ifade etmişlerdir.

\section{Sonuç}

2018 Tarih Dersi Öğretim Programı'nda var olan değerlere ilişkin tarih öğretmen adaylarının değer hiyerarşilerini ortaya koymanın amaçlandığı araştırmada ilk üç tercihinde vatanseverlik, adalet ve dürüstlük değerlerinin öne çıtığı görülmüştür.

Öğretmen adayları 10 değer içinden ilk üçte sıraladıkları vatanseverlik, adalet ve dürüstlük değerleri aynı zamanda toplam değerde de sıralamaya girmiş olup burada adalet değeri vatanseverliğin önüne geçmiştir. Bu bakımdan içerisinde tarih konularını barındıran sosyal bilgiler derslerinde öğretmen adaylarının değer tercihlerine yönelik yapılan çalışmayla (Yılmaz, 2013) birinci sırada vatanseverlik çıkması bakımından benzerlik göstermektedir. Acun, Yücel, Önder ve Tarman (2013) tarafından öğretmen ve veliler üzerinde yapılan çalışmada ise öğretmenlerin en önemli gördükleri değerlerin sirasıyla vatanseverlik, sorumluluk ve adil olma değerlerinin olması ile araştırma arasında benzerlik bulunmaktadır. Ancak bu benzerlik adalet ve dürüstlük değeri açısından bulunmakta vatanseverlik değeri açısından farklılık arz etmektedir. Vatanseverlik bağlamında ise Tokdemir (2007) ile Yiğittir ve Öcal'ın (2011) tarih öğretmenleri üzerine yaptığı araştırmalarla benzeşmektedir.

Programdaki 10 değerden dostluk, öz denetim, sevgi, yardımseverlik değerleri sıralamanın sonların yer almış özellikle yardımseverlik değeri 
hiç bir öğretmen adayı tarafından ilk iki sırada gösterilmemiş, üçüncü sırada ise sadece bir öğretmen adayı tarafından sıraya dahil edilmiştir.

Öğretmen adaylarının değer hiyerarşisinde ilk üçe aldıkları bu değerlere yönelik gerekçelerine bakıldığında;

Vatanseverlik değeri için; vatanına sahip çıkmak, vatanını sevmeyene güvenilemeyeceği, ülkeye faydalı olmak, kendini, ailesini, tarihini sevmek ve birlik-beraberlik içinde yaşamak gibi gerekçeler sunulmuştur. $\mathrm{Bu}$ gerekçeler Çelikkaya ve Kürümlüoğlu (2017) tarafından yapılan çalışma ile çocuğun vatana faydalı olması ve vatanın kutsal olması yönündeki gerekçeleri açısından benzerlik taşımaktadır.

Adalet değeri için; hak- hukuk çerçevesinde hareket etmek, hayatın her alanında lazım olduğu, birlik-beraberlik içinde yaşamak, sorunsuz insani ilişkiler kurmak, örnek vatandaş olmak öne çıkmıştır. Çelikkaya ve Kürümlüoğlu'nun (2017) çalışması ile toplumsal düzenin sağlanması ve insan olmanın gereklerinden biri olduğu için gibi gerekçeler ile farklılık göstermektedir.

Dürüstlük değeri için; kişilik için öncelikli olduğu, saygı ve sevginin kaynağı olduğu gibi gerekçelerle Karatekin, Gençtürk ve Kılıçoğlu (2013) tarafından yapılan çalışma ile farklılık taşımaktadır.

Çocukların tarih programında var olan değerleri kimden kazanmaları gerektiği konusunda öğretmen adayları için ilk üç değerin öğretmenden kazanılması gerektiğini ifade etmişlerdir. Bunun yanında, dini/tarihi karakterlerden ve edebi eserlerden kazanılabileceği ifade edilmiştir. Öğretmen adaylarına göre öğretmen her tür davranışı ile öğrencilerine iyi bir model olmak zorundadır. Öyle ki Aktepe ve Yel'e (2009) göre öğretmenlerin örtük de olsa kendi değer yargılarını öğrencilerine aktarmaktadırlar. Eğitim öğetim sürecinde öğretmenlerin sahip oldukları değerler önemli görülmektedir (Çelikkaya ve Kürümlüoğlu, 2017). Alanyazında öğretmenlerin değerlerin kazandırılmasında önemli payları olduğu düşüncesinden hareketle çalışma (Kolaç ve Karadağ, 2012; Çelikkaya ve Kürümlüoğlu, 2017) ile benzerlik taşımaktadır. Aynı zamanda çalışma Yıldırım'ın (2009) "öğretmenlerin okul ortamında ve dışında değerleri yansıtan örnek model olmalarına" değinen çalışması ile Memiş ve Gedik'in (2010) "öğretmen davranışları, öğrenci davranışlarının belirleyicisidir" bulgusuyla uyuşmaktadır. 
Öğretmen adaylarının bu değerlerin kazandırılmasında izlenecek yöntemler konusunda ise düz anlatım yapılması, örnek olaylara yer verilmesi, model olunması, uygulama yaptırılması, tarihsel filmler ve belgeseller izlettirilmesi ve tarihsel mekanlara gezi yapılması gibi öneriler sunulmuştur. Bu durum Fidan'ın (2009) çalışmasıyla uyumludur. Zira derslerde yöntem ve teknik kullanımı verilmek istenen değerlerin, öğrenciler tarafından özümsenmesini kolaylaştırmaktadır. Tarih öğretimine dair herhangi bir benzer çalışmaya rastlanmazken tarih konularını kapsaması bakımından sosyal bilgiler derslerine yönelik yapılan bir çok çalışmada özellikle adalet değerinin çoğu zaman ilk üç sırada yer alması hem sosyal bilgiler hem de tarih dersleri için adalet değerinin önemsendiğini göstermektedir (Aktepe ve Yel, 2009; Karatekin, Gençtürk ve Kılıçoğlu, 2013; Yılmaz, Göçen ve Yılmaz, 2013).

Değerlerin hangi konularla ilişkilendirilebileceğine ilişkin öğretmen adaylarının görüşleri incelendiğinde; vatanseverlik değerini kazandırmak için geçmişte yapılan savaşlar ile tarihi şahsiyetler konuları oldukça öne çıkmaktadır. Adalet değerini kazandırmak için öne çıkan konular ise Osmanlı padişahlarının şahsiyetleri ile İslam tarihinden Hz. Muhammed ve Hz. Ömer dönemleri olmaktadır. Dürüstlük değeri ise benzer şekilde Osmanlı padişahları ile Hz. Muhammed konuları ilişkilendirilmiştir. Öğretmen adayları tarafından önemsenen değerlerin aktarımında tarihi karakterlerden yararlanılması gerektiği görüşü alan yazındaki bazı çalışmalar ile paralellik göstermektedir (Dönmez, 2006; Dönmez ve Yazıc1, 2009; Fidan, 2009; Ulusoy, 2005).

Araştırmada tarih öğretmen adayları için vatanseverlik, adalet ve dürüstlük değerlerinin ön plana çıtığı; diğer 7 değerin ise önem sıralamasında zayıf kaldığı görülmüştür. Bu bağlamda sıralamada geri planda kalan değerlere yönelik araştırmalar yapılması önerilebilir. Aynı zamanda öğretmen ve/veya öğretmen adaylarının değer hiyerarşileri ile tarih programları ve ders kitaplarında yer alan değerlerin uyuşum oranlarına dair incelemeler yapılabilir. 
EXTENDED ABSTRACT

\title{
Value Hierarchies, Reasons and Recommendations of Pre-Service History Teachers Regarding Value in the History Curriculum
}

\author{
Tercan Yıldirım \\ Ahi Evran University
}

\section{Introduction}

It is necessary to adopt and internalize the values regulating the social life so that it could flow neatly and smoothly. This necessity puts important duties on the values education.

Values education starts in the family first. A planned and programmed values education process is possible only at schools. Therefore, the schools are the most important places in the teaching of values to individuals. Schools have goals such as preparing students for life, have them adopt the values belonging to their society, and have them behave in accordance with these values. The main goal of values education is to raise citizens. The schools play a central important role in creation of new values in addition to protection and continuance of the existing values and culture.

The most important responsibility in values education is attributed to teachers. Considering especially socialization of students, we encounter with the role-model potential of teachers. How the values involved in the curriculums are perceived by their teachers and which of these values are attached more importance them have a direct effect on education process because people have a values hierarchy that constitutes their values system. When a person is asked to sort the values, it is accepted that the first value mentioned is the most important one for that person. The person stays under the influence of his/her own values system while sorting them. With reference to teachers' primary role in values educa- 
Tarih Öğretmen Adaylarının Programdaki Değerlere İlişkin Değer Hiyerarşileri, Gerekçeleri ve Önerileri

tion, it is important to determine their values hierarchy for the implementation of curriculum.

\section{Purpose}

The purpose of this study was to reveal the first three choices of preservice history teachers studying pedagogical formation out of ten stem values in new history curriculum, why they chose those values, and what their suggestions on teaching of these values were. Thus, which values were attached the most and least importance by preservice history teachers were determined. Moreover, their values hierarchies were revealed to build up the values profile possessed by preservice history teachers who have the potential to transmit values in the future. At this point, it can be stated that revealing the values hierarchy of preservice history teachers is important in terms of development of values proposed in the curriculum.

\section{Method}

In this qualitative research, case was used to reveal preservice history teachers' values hierarchy and their reasons. Case study is a research method as an empirical inquiry that investigates a contemporary phenomenon within its real-life context; when the boundaries between phenomenon and context are not clearly evident; and in which multiple sources of evidence are used.

\section{Participants}

The participants of this study involved 61 preservice history teachers studying pedagogical formation at a state university in 2017-2018 academic year.

\section{Data Collection and Analysis}

Structured interview form composed of 4 open-ended questions was used as the data collection tool. Inductive analysis, one of the content 
analysis techniques, was used to analyze the data. Inductive analysis is carried out to reveal the concepts underlying the data through coding and the relationships among these concepts.

\section{Findings and Conclusion}

In this study aiming at revealing the preservice history teachers' values hierarchy regarding the values involved in 2018 history curriculum, it was found that patriotism, justice, and honesty were listed in the first three rankings by participants. These values were also ranked among the total values, but justice left the patriotism behind.

When the preservice history teachers' reasons of mentioning these values in the first three rankings were examined, it was found that some reasons for patriotism were listed such as protecting one's own country, not trusting those who don't love the country, being beneficial to the country, loving his/herself, his/her family, and history, and living together in harmony. For the justice value, the following reasons were listed: acting in accordance with rights and laws, its necessity in every part of the life, living together in harmony, making hassle-free interactions, and being a model citizen. As for the honesty value, it was indicated that it was a priority for a solid character and the source of love and respect.

The preservice teachers indicated that the students should develop these three values with the guidance of their teachers. Moreover, they expressed that religious/historical characters and literary works were other sources. According to preservice teachers, the teachers should be a good role model for their students in every aspect. Preservice teachers suggested using direct instruction, giving sample cases, being a model, practices, watching historical movies and documentaries, and visiting historical places regarding the ways of teaching these values.

When the preservice teachers' opinions regarding the topics that could be associated with the values were examined, it was observed that they suggested the past wars and historical characters for teaching patriotism. Ottoman sultans, Prophet Muhammed, and his companion Omar were suggested to teach the justice. Similarly, Ottoman sultans and Prophet Muhammed were suggested for teaching honesty. 
In accordance with the findings, it can be recommended for future research to focus on the values on the lower rankings in the preservice teachers' list. Moreover, it is also recommended to reflect these values in more detail and exploratory in curriculum and include some courses regarding the values education of preservice teachers.

\section{Kaynakça / References}

Acun, İ., Yücel, C., Önder, A. ve Tarman, B. (2013). Değerler: kim ne kadar değer veriyor? Uşak Üniversitesi Sosyal Bilimler Dergisi, 6(1), 191-206

Aktepe, V. ve Yel, S. (2009). İlköğretim öğretmenlerinin değer yargılarının betimlenmesi: Kırşehir ili örneği. Türk Eğitim Bilimleri Dergisi, 7(3), 607-622.

Aydın, M. (2003) Gençlerin değer algısı. Değerler Eğitimi Dergisi, 3,121144.

Balcı, F. A. ve Yelken, T. Y. (2010). İlköğretim öğretmenlerinin "değer" kavramına yükledikleri anlamlar. Hacettepe Üniversitesi Ĕ̆itim Fakültesi Dergisi, 39, 81-90.

Bartelds, B. F. and Debats, D. L. (1995). The structure of human values: a principal components analysis of therokeach value survey. British Journal of Social Psychology, 41, 77-86.

Çelikkaya, T. (2016). Sosyal bilgiler programındaki değerlere ilişkin sosyal bilgiler öğretmen adaylarınn değer öncelikleri ve gerekçelerine ilişkin görüşleri. The 2nd International Conference on the Changing World and Social Research (ICWSR'2016) October, 14-16, 2016, proceedings book s.945-962, Barcelona-SPAIN

Çelikkaya, T. ve Kürümlüoğlu, M. (2017). Veliler, öğrenciler ve sosyal bilgiler öğretmenlerinin 2005 programdaki değerlere ilişkin değer hiyerarşileri, gerekçeleri ve önerileri. Uluslararası Sosyal ve Ĕgitim Bilimleri Dergisi, 4(8), 243 - 264. http://dx.doi.org/10.20860/ijoses.338565

Çelikkaya, T. ve Öztürk Demirbaş, Ç. (2013). Sosyal bilgiler öğretmen adaylarının sosyalbilgiler öğretim programındaki değerlere ilişkin görüşleri. The Journal of Academic Social Science Studies. 6(5), 527-556. Doi number:http://dx.doi.org/10.9761/JASSS1617 
Çelikkaya, T. ve Yakar, H. (2015). Sosyal bilgiler programında gazete, dergi ve internet haberlerinin kullanilması. Turkish Studies, 10(3), 251-270. Doi: http://dx.doi.org/10.7827/TurkishStudies.7652.

Demircioğlu, İ. H. ve Tokdemir, M. A. (2008). Değerlerin oluşturulma sürecinde tarih eğitimi: Amaç, işlev ve içerik. Değerler Ĕ̆itimi Dergisi, 6(15), 69-88.

Demircioğlu, İ.H. (2010). Tarih öğretiminde öğrenci merkezli yaklaşımlar. Ankara: Anı Yayıncılık

Dewey, J. (2000). Temel eğitiminde tarihin amacı. (Çev: B. Ata), Milli Eğitim Dergisi, 147.

Dilek, D. (2007). Tarih derslerinde öğrenme ve düşünce gelişimi. Ankara: Nobel Yayın Dağıtım.

Doğan, İ. (2011). Eğitim sosyolojisi. Ankara: Nobel Yayınları.

Dönmez, C. (2006). Değerler eğitiminde kahramanların kullanımına bir örnek: Mustafa Kemal Atatürk. Gazi Eğitim Fakültesi Dergisi, 26, 113-133.

Dönmez, C. ve Yazıcı, K. (2009). Atatürkçülüğ̈un bir üst değer olarak öğretimi. Gazi Ĕ̆itim Fakültesi Dergisi, 29, 1467-1490.

Ergün, M. (1994). Eğitim sosyolojisine giriş. Ankara: Ocak Yayınları.

Fidan, N. K. (2009). Öğretmen adaylarının değer öğretimine ilişkin görüşleri. Kuramsal Ĕ̆itimbilim, 2 (2), 1-18

Gülmüş, R. (2015). İlkokul 4. sinıf sosyal bilgiler dersi tarih konularında değer öğretimine ilişkin sını öğretmeni görüşleri. Yüksek lisans tezi, Mehmet Akif Ersoy Üniversitesi, Burdur.

Gültekin, F. (2011). Tarih öğretiminde değerler. M. Safran (Ed.), Tarih Nasıl Öğretilir (s. 131- 137). İstanbul: Yeni İnsan Yayınevi.

Güngör, E. (2000). Değerler psikolojisi üzerine araştırmalar. İstanbul: Ötüken Yayınları.

Halstead, J. M. and Taylor, M. J. (2000). Learning and teaching about values: A review of recent research. Cambridge Journal of Education. 30(2), s.169-202.

Karatekin, K., Gençtürk, E. ve Kılıçoğlu, G. (2013). Öğrenci, sosyal bilgiler öğretmen adayı ve öğretmenlerinin değer hiyerarşisi. Adryaman Üniversitesi Sosyal Bilimler Enstitüsü Dergisi, 6(14) , 411-458.

Keskin, Y. (2008). Türkiye'de sosyal bilgiler öğretim programlarında değerler eğitimi: Tarihsel gelişim, 1998 ve 2004 programlarmm etkililiğinin 
Tarih Öğretmen Adaylarının Programdaki Değerlere İlişkin Değer Hiyerarşileri, Gerekçeleri ve Önerileri

araştırılması. Yayınlanmamış doktora tezi, Marmara Üniversitesi, İstanbul.

Keskin, Y. (2015). Tarih dersi öğretim programı ve ders kitaplarında değerler eğitimi. TurkishStudies, 10(7), 659-674. Doi: http://dx.doi.org/10.7827/TurkishStudies.8234

Kolaç, E. ve Karadağ, R. (2012). Türkçe öğretmeni adaylarının "değer" kavramina yükledikleri anlamlar ve değer siralamaları. İlkögretim Online, 11(3), 762-777.

Marshall, G. (2009). Sosyoloji sözlüğü. (Çev., Osman Akınhay ve Derya Kömürcü). Ankara: Bilim ve Sanat Yayınları.

Memiş, A. ve Gedik, E. G. (2010). Sınıf öğretmenlerinin değer yönelimleri. Değerler Eğitimi Dergisi, 8(20), 123-145.

Miles, M, B. and Huberman, A. M. (1994). Qualitative data analysis: An expanded source book. ThousandOaks, CA: Sage.

Mutluer, C., (2015). Tarih derslerinin değer eğitimindeki yeri: tarih öğretmenlerinin görüşleri. Turkish Studies, 10(15), 649-666. Doi: http://dx.doi.org/10.7827/TurkishStudies.8949, p.

Nichol, J. (1996). Tarih eğitimi. (Çev. M. Safran) Ankara: Çağrı Matbaası.

Nichol, J. and Dean, J., (1997). History 7-11 developing primary teaching skills. London: Routledge.

Paykoç, F. (1998). Tarih öğretiminde duyuşsal alanın rolü. Salih Özbaran (Ed.), Tarih Öğretimi ve Ders Kitapları (s. 85-93). İzmir: Dokuz Eylül Yayınları.

Safran, M (2006). Tarih eğitimi makale ve bildiriler. Ankara: Gazi Kitabevi.

Safran, M. (1993). Tarih oğretiminin eğitimsel amacları. Belleten, 57(220), 827-842.

Tezcan, M. (1999). Eğitim sosyolojisi. Ankara

Tokdemir, A. (2007). Tarih öğretmenlerinin değerler ve değerler eğitimi hakkındaki görüşleri. Yüksek lisans tezi, Karadeniz Teknik Üniversitesi, Trabzon.

Tokdemir, A. ve Demircioğlu İ. (2008). Değerlerin oluşması sürecinde tarih öğretimi. Değerler Ĕ̆itimi Dergisi, 6(15), 69-88.

Tokdemir, M.A. (2016). Değerler mi beceriler mi: Tarih öğretiminin amaçlarına ilişkin tarih öğretmen adaylarının görüşleri. Turkish Studies,

22252242.Doi:http://dx.doi.org/10.7827/TurkishStudies.9027 
Ulusoy, K. (2003). Sosyal bilgiler öğretmenlerinin tarih ve ahlak eğitimi ilişkisi üzerine görüşleri. Yüksek lisans tezi, Gazi Üniversitesi, Ankara.

Ulusoy, K. (2005) Tarih derslerinde ahlaki değerlerin aktarımı: Bir okuma parçası örneği. Milli Ĕ̆itim, 168, 126-133.

Ulusoy, K. (2007a). Lise tarih programinda yer alan geleneksel ve demokratik değgerlere yönelik öğrenci tutumlarının ve görüşlerinin çeşitli değişkenler açısından değerlendirilmesi. Yayınlanmamış doktora tezi, Gazi Üniversitesi, Ankara.

Ulusoy, K. (2007b). Sosyal bilgiler oğretmenlerinin tarih ve ahlak eğitimi ilişkisi uzerinegoruşleri (Sakarya il orneği). Değerler Eğitimi Dergisi, 5(13), 155-177.

Ulusoy, K. (2007c). Lise tarih programinda yer alan geleneksel ve demokratik değerlere yönelik öğrenci tutumlarının ve görüşlerinin çeşitli değişkenler açısından değerlendirilmesi. Yayınlanmamış doktora tezi, Gazi Üniversitesi Eğitim Bilimleri Enstitüsü, Ankara.

Ulusoy, K. (2010). Değer eğitimi: Davranışçı ve yapılandırmacı yaklaşıma göre hazırlanan tarih programlarında değer aktarımı. Trakya Üniversitesi Sosyal Bilimler Dergisi, 12(1), 32-51.

Ulusoy, K. (2016). Sosyal bilgiler öğretiminde değer aktarımı ve eokuma. Ahi Evran Üniversitesi Kırşehir Eğitim Fakültesi Dergisi (KEFAD), 17(1), 401-418.

Yaşar ve Çengelci (2012). Sosyal bilgiler dersinde değerler eğitimine ilişkin bir durum çalışması. Uluslararası Avrasya Sosyal Bilimler Dergisi, 3(9), 1-23.

Yazıcı, F. (2011). Cumhuriyet dönemi tarih ders kitaplarında tarihyazimı.V. Engin ve A. Şimşek. (Ed.), Türkiye'de Tarihyazım (s. 197219). İstanbul: Yeditepe Yayınevi.

Yazıcı, K. (2006). Değerler eğitimine genel bir bakış. Türklük Bilimi Araştırmalart, 19, 499-522.

Yeşil, R. ve Aydın, D. (2007). Demokratik değerlerin eğitiminde yöntem ve zamanlama. TSA, 11(2), 65-84.

Yiğittir, S. ve Öcal, A. (2011). Lise tarih öğretmenlerinin değerler ve değerler eğitimi konusundaki görüşleri. KMÜ Sosyal ve Ekonomik Araştırmalar Dergisi, 13(20),117-124.

Yıldırım, A., ve Şimşek, H. (2008). Sosyal bilimlerde nitel araştırma yöntemleri. Ankara: Seçkin Yayıncılık. 
Tarih Öğretmen Adaylarının Programdaki Değerlere İlişkin Değer Hiyerarşileri, Gerekçeleri ve Önerileri

Yıldırım, K. (2009). Values education experiences of Turkish class teachers: A phenomonological approach. Eurasian Journal of Educational Research, 35, 165-184.

Yıldırım, T. (2016). Tarih ders kitaplarında kimlik söylemi. İstanbul: Yeni İnsan Yayınevi.

Yıldırım, T. (2017). Yeni ortaöğretim tarih ders programları ve 9. sınıf tarih ders kitabında değerler eğitimi. Turkish Studies, 12(33), 557572 DOI Number: ttp://dx.doi.org/10.7827/turkishstudies.12533

Yılmaz, E. (2009). Öğretmenlerin değer tercihlerinin bazı değişkenler açısından incelenmesi. Değerler Eğitimi Dergisi, 7(17), 109-128.

Yılmaz, F., Göçen, S. ve Yılmaz, F. (2013). Sokakta çalışan ve çalışmayan ilköğretim öğrencilerinin sosyal bilgiler programındaki değerlere ilişkin algıları. E-Uluslararası Ĕ̆itim Araştırmaları Dergisi, 4(1), 82-99

Yılmaz, S. (2013). Sosyal bilgiler dersinde kazandırılması amaçlanan değerlere ilişkin öğretmen adayı görüşleri. Adıyaman Üniversitesi Sosyal Bilimler Enstitüsü Dergisi, 6(14), 645-680.

Yin, R. K. (2003). Case study research: Design and methods. London: Sage Publications.

\section{Kaynakça Bilgisi / Citation Information}

Yıldırım, T. (2018). Tarih öğretmen adaylarının programdaki değerlere ilişkin değer hiyerarşileri, gerekçeleri ve önerileri. OPUS Uluslararası Toplum Araştırmaları Dergisi, 8(14), 296-320. DOI: 10.26466/opus.404219 